\title{
Occupational therapy's link to vocational reeducation, 1910-1925.
}

Sharon A. Gutman

Follow this and additional works at: https://jdc.jefferson.edu/otfp

Part of the Occupational Therapy Commons

Let us know how access to this document benefits you

\section{Recommended Citation}

Gutman, Sharon A., "Occupational therapy's link to vocational reeducation, 1910-1925." (1997).

Department of Occupational Therapy Faculty Papers. Paper 36.

https://jdc.jefferson.edu/otfp/36

This Article is brought to you for free and open access by the Jefferson Digital Commons. The Jefferson Digital Commons is a service of Thomas Jefferson University's Center for Teaching and Learning (CTL). The Commons is a showcase for Jefferson books and journals, peer-reviewed scholarly publications, unique historical collections from the University archives, and teaching tools. The Jefferson Digital Commons allows researchers and interested readers anywhere in the world to learn about and keep up to date with Jefferson scholarship. This article has been accepted for inclusion in Department of Occupational Therapy Faculty Papers by an authorized administrator of the Jefferson Digital Commons. For more information, please contact: JeffersonDigitalCommons@jefferson.edu. 


\section{Occupational Therapy's Link to Vocational Reeducation, 1910-1925}

\author{
Sharon A. Gutman
}

Key Words: reconstruction aides (World War I)

Sharon A. Gurman, MA, OTR/L, is Research Associare, Department of Occupational Therapy, Thomas Jefferson University, Edison Building, Suire 820, 130 South 9th Street, Philadelphia, Pennsylvania 19107-5233.

This article was accepted for publication February 18, 1997.
The development of occupational therapy is rooted in early 20 th century medical reform. During the early 1910 s, several members of the medical profession, human service workers, and the larger American society were increasingly disturbed by medical practices that did not consider the individual's personal experience of disability. Occupational therapy was developed, in part, out of this desire to provide persons with treatment that helped them to function in their communities despite their disability. Early occupational therapy leaders envisioned the fledgling profession as a societal service capable of assisting persons with disabilities to return to both work and community life. Vocational reeducation was initially considered to be an integral component of occupational therapy in the years from 1910 to 1920. However, the profession's early link to vocational reeducation was challenged by vocational technical trainers during World War I. To prevent occupational therapy from being subsumed by vocational technical training, the early occupational therapy leaders implemented several strategies: adoption of physician prescription for all occupational therapy services, delivery of occupational therapy services primarily within hospital settings, and dissociation from vocational reeducation services. Reasons accounting for why the early occupational therapy leaders abandoned their initial commitment to vocational reeducation are explored. Sugoestions about how this decision has affected present-day practice are also offered.

$\mathrm{T}$ The profession of occupational therapy grew out of several social movements that were popular at the turn of the century: antimodernism, the artsand-crafts movement, progressive educational reform, moral treatment, and the mental hygiene movement (Colman, 1984; Levine, 1987; Litterst, 1992; Peloquin, 1989, 1994; Quiroga, 1995; Schemm, 1994; Schwartz, 1992). During the early 1900s, another group of reformers sought to transform the profession of medicine. This reform of the medical profession was based on a reaction against medicine's increasing devaluation of the patient's personal experience of illness and disability. The group of reformers was composed of both medical and nonmedical professionals. Physician reformers included Adolph Meyer, Edgar King, Joel Goldthwait, Herbert Hall, Ellior Brackert, and William Rush Dunton. Nonphysician reformers included George Barton, Rev. Elwood Worcester, Thomas Kidner, Eleanor Clarke Slagle, Julia Lathrop, and Susan Cox Johnson. In 1905, Worcester founded the Emmanuel Movement, a popular self-help movement 
that integrated scientific, psychoanalytic, and spiritual approaches to the treatment of illness (Worcester \& McComb, 1931). The Emmanuel Movement was an attempt at medical reform that coincided with the development of occupational therapy but did not compete with 20 th century health care methods. However, there is evidence that Worcester professionally collaborated with physicians who were instrumental in the development of occupational therapy, including Barton, Hall, and Goldthwait ("An Advisory Medical Board for the Emmanuel Movement," 1909; Barton, 1914).

These early medical reformers believed that a gap existed in medicine that caused patients to be released from hospitals unfit for what is commonly referred to today as community reintegration. Although these reformers recognized that medicine must address the acute illness of patients, they also contended that patients required medical assistance to rejoin society as contributing members. Medical treatment that only addressed acute physical pathology, but left patients chronically disabled in the community, was considered ineffectual. Instead, medical reformers demanded that medicine begin to address how persons with chronic disabilities could be rehabilitated to regain functional participation in all aspects of community life, including work. For example:

I say that to discharge a parient from the hospital, with his fracture healed, to be sure, but to a devastared home, to an empoy desk, and to no obvious sustaining employment, is to send him out to a world as cold and bleak, as much to be feared and shrunk from as is that of the convict, who, upon release from Sing Sing is given five dollars, a warm suit of clothes and a ticket to New York. (Barton, 1914, p. 329)

Up to the present, the whole hospital world has restricted itself to the fight against pain and death. To get the patient well has been the aim and the end of it all... But the hospital world [must] expand, as the public is demanding that it shall expand, so that to merely get the parient well is not the whole thing, but to get him well for something. (Barron, 1920, p. 305)

Doctors do nor give sufficient thought to... realize that despite proper surgical and medical treatment, persons are being discharged from the hospiral unfit to go back to work. (Elton, 1924, p. 103)

These medical reformers believed that occupational therapy could fill the gap created by a medical model that only addressed pathology and increasingly neglected to consider how persons with disabilities can rebuild lives in their communities:

When the physician subordinates the individual [parient] case to some classification of disease and some generic rule of treatment, he sinks to the level of the routine mechanic. With this in mind it is not difficult to see that occupational therapy belongs as an integral part of the arr of medicine. There is no form of therapy that requires closer adapration to the needs of the individual parient, and whose proper application requires a more thorough knowledge of the patient as a whole, including his temperament, his background, his mental status, as well as the character and extent of his physical disability. (Robinson, 1924, p. 1)
The medical profession... has loosen[ed] the personal ties between doctor and patient.... Occupational therapy may serve as a link to draw the plyysician back to a closer personal relationship with his patients, especially in hospital care. The physician's greatest mental effort is necessarily often spent on the medical problems concetning the disease or injury of the patient. The mind of the occupational therapist must be constantly focused on the individual... I have found such cooperation a great help in realizing a full understanding of the situation of which the disease or injury of the patien is only a part....The occupational therapist should be ready and eager to rake advanrage of the opportunity that her intimate contact with parients affords, and encourage the medical profession to give constant thought to the individual problems inherent in illness and surcounding each patient. (Robinson, 1924, p. 3)

If they are fully appreciated occuparional therapy may indeed take a leading role in bringing back some of the funcrions of the physician which modern merhods tend to suppress. (Robinson, 1924, p. 5)

\section{Occupational Therapy: Restoration to Social Usefulness}

These medical reformers, who became early proponents of occupational therapy, sought to fill the existing gap in medicine with a health care profession that could rehabilitate persons with disabilities to social usefulness. Occupational therapy was to be that missing medical link. The early leaders envisioned occupational therapy as a form of medical rehabilitation that would bridge the gap between acute surgical and pharmaceutical treatment and reentry into the community (Barton, 1914, 1915; Dunton, 1915, 1928; Hall \& Buck, 1915; Robinson, 1924).

In the early 1910 s, a need to restore persons with disabilities to social usefulness was created by surging numbers of industrial work-related accidents. Elizabeth Upham (1917b), one of the founders of occupational therapy, contended:

Inasmuch as all the value of occuparional therapy may be derived from work of a practical rype, the time of convalescence may be used as a period of vocarional training. Ac the same time he [the paticnt] is recovering he will be reeducating himself for his old occupation or training himself for a new one, as the case may be. (p. 9)

Similarly, Frederic G. Elton (1924), a physician involved in medical reform and a supporter of occupational therapy, wrote that

rehabilitation means restored to the former [life] position...in so far as it is physically, mentally, and vocarionally possible. There is the repair of the human machine, or physical and anatomical reconstruction. There is the working out of the various [bodily] parts after they have become stiff with disuse. There is the rebuilding of the morive power or the reconstruction of confidence and grit. There is the replacement of the individual in some form of occupation. (pp. $102-103)$

Kidner (1925), a Canadian architect, served with Upham on the U.S. Federal Board for Vocational Education and was a founding member of the National Society for the Promotion of Occupational Therapy (NSPOT). Kidner believed that occupational therapists could offer 
vocational reeducation to workers with disabilities within the community hospital setting. He envisioned the hospital preindustrial shop as a clinic staffed by therapists who could provide the physical retraining of disabled muscles, joints, and nerves in order to facilitate patients' return to the workplace:

The pre-industrial shop is but one step, or link in the chain, in the process of the return to usefulness of sick and disabled persons; a process that, to be fully effecrive, should be a continuous one, and should moreover, begin as soon as possible in the history of every hospital case. (p. 187)

The purpose of a pre-industrial shop is to assist the patient in his readjustment to normal living by affording opporrunity for the development of habits of industry that have been impaired by disease or accident. (p. 188)

However, although the early occupational therapy leaders believed that the new profession could meet the societal need of rehabilitating persons with disabilities to become contributing, self-supporting members of society, the leaders did not want physicians and the public to confuse occuparional therapy with technical vocational training. Technical vocational training was viewed as education in specific trade skills necessary to obtain employment. Conversely, occupational therapy vocational reeducation was perceived as (a) the retraining of disabled muscles, joints, and nerves to perform general work skills and (b) the rebuilding of prework skills eroded by prolonged hospitalization. Occuparional therapists would teach persons with disabilities to relearn the physical and cognitive skills necessary to perform work and community activities, in accordance with each person's unique disabilities. This early definition of occupational therapy vocational reeducation resembles the profession's modern specialty of work hardening.

The leaders were cautious to preserve the distinction between occupational therapy vocational reeducation and technical vocational training. Kidner (1925) assumed a decided stance that the purpose of the hospital preindustrial shop was entirely curative and did not serve the function of vocational training. Similarly, Dunton (1915) argued that "a person may in the enthusiasm for the [occuparional therapy] work, lose sight of the special object of occupational therapy, which is to develop the [work] initiative of the patient and not to make him a trained craftsman" (p. 36). Johnson (1919) also feared that the public and medical profession woulu nor appreciate the medical importance of occupational therapy and would confuse the profession with technical vocational training. In literature describing occupational therapy, the early leaders took advantage of all opportunities to define the profession as a medical therapy. For example:

Occupational therapy aims to furnish a scheme of scientifically arranged acrivities which will give, to any set of muscles or related parts of the body in cases of disease or injury, jusr the degree of movement and exercise that may be directed by a comperent physician or surgeon [tol stimulate hearr action, respiration, and blood circulation, as prescribed. (Dunton, 1928, p. 3)

Thorough knowledge of anaromy and kinesiology, with fundamental points and principles involved in the various btanches of medicine, and the ability to properly interpret and apply the doctor's diagnosis are the first requirements of the occupational therapisr. (Dunron, 1928, p. 14)

Occuparional therapy provides occuparion which will produce a similar therapeutic effect to that of every drug in materia medica. An exercise for each separate organ, joint, and muscle of the human body. (Barton, 1915, p. 139)

\section{Professional Affiliation With Prominent 20th Century Orthopedists}

To secure an understanding of occupational therapy as a medical health profession, the early leaders used their social connections to prominent medical leaders. Two such medical leaders were Goldthwait and Brackett, borh Harvard-educated orthopedists practicing in the Boston area ("Letter to E. G. Brackett," 1918; Osgood, 1916; "Reconstruction and Rehabilitation of Disabled Soldiers," 1918). Hall, the first president of NSPOT, was also a Harvard-trained physician who was married to Goldthwait's sister (Hall, 1917; Hall \& Buck, 1915; "Interests of Women," 1918). Through Hall, Goldthwait and Brackett became professionally associated with several of the founding members of NSPOT, particularly Duncon (also an ivy league-educated physician), Kidner, and Slagle ("Letter to J. E. Goldthwait," 1918c).

Goldthwait and Brackett were leaders of the American Orthopedic Association (AOA), a newly organized medical profession seeking to enhance irs status and professional opportunities (Goldthwait, 1917; Mayer, 1917). These orthopedists shared with the early occupational therapy leaders the view that medical stabilization alone was insufficient in the care of persons with disabilicies. They argued instead that restoration and maximization of joint, muscle, and nerve funcrion must follow acute medical care in order to return the person to the community as a functioning member of society (Chamberlain, n.d.; Goldthwait, 1917; Mayer, 1917).

In 1916, Goldthwait and Brackett drew up World War I (WWI) preparedness plans in which they offered the services of the AOA to the Surgeon General, pending U.S. entry in the war ("The Function of Orthopedic Surgery," 1917; "Organization of Orthopedic Service," n.d.; "Plan Suggesred for Conducting Orthopedic Service," 1918). These plans were based on the English reconstruction hospital and entailed three stages of rehabilitation: (a) acure orthopedic surgical care, (b) bedside and curative workshop occupational therapy (administered 
during the period of convalescence), and (c) vocational reeducation instituted before hospital discharge ("Letter to Sir George Makins," 1918; "The Scope of a Reconstruction Hospital," 1917). Bedside and curative workshop occupations were to involve the rehabilitation of impaired joints, muscles, and nerves. Vocational reeducation would involve the retraining of disabled soldiers, in accordance with their individual abilities and limitations, in appropriate work skills in preparation for return to military service or civilian life.

Goldthwait and Brackett intended that occupational therapists would provide all the bedside and curative workshop therapies and a major portion of the vocational reeducation skills ("Interests of Women," 1918; "Plan Suggested for Conducting Orthopedic Service," 1918). Male vocational trainers would also be enlisted to provide education in new trades if war injuries prevented soldiers from returning to former occupations. The orthopedists planned to oversee the direction of all three stages of reconstruction ("The Function of Orthopedic Surgery," 1917; Mayer, 1917).

The Surgeon General approved the AOA's war plans and created the Division of Orthopedic Surgery within the Medical Department of the Army. However, the War Department delayed approval for reconstruction plans until the United States had been involved in the war for more than 1 year. When approval finally arrived from the War Department, it was granted for a reconstruction program that was considerably scaled down from the AOA's original proposal ("Circular Letter No. 29, SGO, 1919," as cired in Lynch, Weed, \& McAfee, 1923).

In reaction to this delay, Goldthwait and Brackett decided to implement their unauthorized reconstruction plans by placing a group of female reconstruction aides (i.e., occupational therapists, physiotherapists) at Walter Reed Hospital in February of 1918 (Crane, 1927; "Letter to J. E. Goldthwait," 1918b). Before the end of 1918, and before Army approval was granted for any reconstruction plans, Goldthwait and Brackett had established reconstruction aide programs in six U.S. base hospitals (Crane, 1927).

In civilian life, Goldthwait's wife, Jessie, and Bracketr's sister, Minnie, founded the Boston School of Occupational Therapy —one of the first war emergency courses designed to train occupational therapists in the administration of occupation to disabled soldiers ("Gorgas Chooses Boston," 1918; Greene \& Wigglesworth, 1921; "Interests of Women," 1918). Other society women, who traveled in the same social circle as Jessie Goldthwait and Minnie Brackett, used their connections to charitable associations to create War Emergency Reconstruction Aide Courses in such cities as New York, Philadelphia, Chicago, and Washington, DC (Ball, 1921; "Fifth Annual Meeting,"
1922; Fulton, 1921; Kidder, 1921; Mansfield, 1956; Partridge, 1921). These schools were designed in the same model as medical school training, which required both classroom and hospital experience, and relied on prominent physicians as lecturers and board members (Bail, 1921; Fulton, 1921; "Occupational Therapy at the College of St. Catherine," n.d.; Partridge, 1921).

In fact, Goldthwait and Brackett originally wanted WWI reconstruction aides to be called medical aides ("Letter to J. E. Goldthwait," 1918a, 1918b). The term reconstruction aide was chosen in 1918 when the Division of Physical Reconstruction was created by the Medical Department of the Army to oversee all aspects of the orthopedists' reconstruction plans, including bedside occupations, curative workshop activities, and vocational reeducation ("Official Memorandum, SGO, May 6, 1918," as cited in Lynch et al., 1923). The Division of Physical Reconstruction was to be headed by orthopedists; however, territorial disputes delayed the implementation of all Physical Reconstruction plans during the first year of U.S. involvement in WWI ("Letter to J. E. Goldthwait," 1918a). At this time, the Federal Board for Vocational Education (a nonmilitary governmental agency) challenged the orthopedists for control over the vocational reeducation of disabled soldiers (Crane, 1927; Federal Board for Vocational Education, 1918; Harris, 1919). In response to this conflict, the War Department usurped the Medical Department of the Army's power and created the Education Service, a nonmedical military division intended by the War Department to oversee Physical Reconstruction plans. The Education Service was composed of vocational trainers responsible for the technical trade training of disabled soldiers who were unable to return to military service or former occupations (Crane, 1921, 1927; Lynch et al., 1923). Because the War Department believed that occupational therapy was not a medical specialty but rather prevocational training, reconstruction aides were moved to the Education Service under the direction of technical vocational trainers (Crane, 1921, 1927; "Letter to J. E. Goldthwait," 1918a, 1918b). The orthopedists' role in the reconstruction program was circumscribed to acute medical care.

\section{Technical Vocational Trainers in WWI}

The Education Service was composed primarily of civilian men having some knowledge of a trade. Enlisted men were initially sought but difficult to secure because the Armistice (November 11, 1918) coincided with the creation of the Education Service. Consequently, men who became vocational trainers often lacked prior teaching experience and seldom possessed medical knowledge. They did not understand the philosophy underlying therapeutic vocational reeducation as envisioned by orthopedists 
and occupational therapists. Instead, vocational trainers believed that they were appointed only to offer instruction in trades (Crane, 1921; Harris, 1919).

The reconstruction aides, who were placed under the vocational trainers' charge, were viewed as prevocational trainers. Their work was considered to be preparation for the more serious task of vocational trade training, as demonstrated by the following accounts written by Education Service vocational trainers:

\footnotetext{
The bedside or ward occupation are of three general kinds, classified according to the purposes for which they are used. The first [two] groups consist of work of such a character as not only to give diversion but also to give a start in a kind of avocation, side-line or hobby. The third group is made up of definite vocational courses of work or study directly connected with the patient's former or proposed occupations.... Not only do bedside courses keep the men busy and contented and provide them with interesting avocations rhat may become quite profitable, but they likewise become feeders for the regular vocational education courses. (Vaughn, 1919, p. 15)
}

Vocational trade training was perceived as the ultimate goal, without which occupational therapy had little meaning or value:

Occupational therapy...usually consists of basket making, whitcling, bead stringing, crocheting, weaving, wood carving, and other simple hand crafts requiring only simple tools and equipment.... It fell to the Army to develop a type of occupational therapy having a direct relation to industries and making a contribution to the eventual teeducation of the disabled man. (Henderson, 1920, p. 326)

A great many mistaken ideas abour the psychology of the disabled soldier have been current. The theory has been advanced that the injured man was encouraged to make an effort by providing him with simple occupations such as bead work, basket making, erc. To many men the mere offering of such work, or the consequent suggestion that such juvenile or feminine occupations ate the limit of his abilities is of irself depressing. The suggescion, however, that there is a real man's job thar he can do, in spite of his handicaps, has the opposite effecr. (Henderson, 1920, p. 326)

Occupational therapy leaders were against the move to reposition the reconstruction aides from the Division of Orthopedic Surgery to the Education Service. They correctly anticipated that occupational therapy would be misperceived as vocational technical training rather than medical therapy. Without the protection of their orthopedic allies, occupational therapy leaders feared that continued development of the profession would be removed from their control and placed within the hands of vocational trainers (Dunton, 1922; Hall \& Buck, 1915; Johnson, 1919).

\section{Reconstruction Aides Break Professional Affiliation With Vocational Education}

During this time, occupational therapy leaders strategized to break their association with vocational educators in WWI. The idea of being governed by tradesmen was nor a thought welcomed by several of the occupational thera- py founders, particularly Slagle, Dunton, and Hall. These occupational therapy leaders planned to develop the fledgling field into a profession composed of well-educated and highly experienced women. Slagle, in particular, established a policy of recruiting upper-class, college-educated women who shared the same social class and cultural background as that of many prominent physicians. Slagle hoped that this policy would allow occupational therapy to develop autonomous of rather than subordinate to medicine, as nursing had developed. She reasoned that women from the same social class and educational background as that of physicians would be less willing to allow the profession to be subjugated by medicine and would understand how to negotiate with physicians to obtain necessary professional assistance ("Fifth Annual Meeting," 1922). The effort to maintain alliance with orthopedists, while dissolving all ties to vocational educators, was a political strategy for the early occupational therapy leaders to preserve control over the development of the profession. Female occupational therapy leaders, in particular, often exercised social agency behind closed doors, that is, in the context of family and social relationships. Because many of the early occupational therapy leaders were socially connected to prominent physicians (often through marriage or family friendship), they remained in control of professional events by using these ties to exert influence.

When the War Department split the reconstruction program in half, thus separating the Division of Orthopedic Surgery from occupational therapy and vocational reeducation, occupational therapy leaders moved to secure their profession's association with orthopedists. One strategy enacted to preserve occupational therapy's alignment with medicine was the adoption of the physician prescription for all occupational therapy services. Slagle advocated strongly for physician prescriptions for several reasons. She knew that physician involvement in occupational therapy would advance the prestige of the growing profession, and she hoped that requiring physicians to provide occupational therapy prescriptions would result in the enhancement of physicians' knowledge of occupational therapy services. Moreover, Slagle realized that a physician prescription would protect occupational therapy from being subsumed by nonmedical specialties, such as technical vocational training. With a physician prescription, occupational therapy would more likely be accepted by the public as a medical health profession ("Fifth Annual Meeting," 1922).

A second strategy to secure occupational therapy medical alignment involved the administration of all occupational therapy services within the hospital setting. Just as the 20th century physician had begun to leave behind treatment in the patient's home for treatment 
within the hospital, occupational therapy would similarly follow. Dunton, Hall, and Kidner, in parcicular, believed that occupational therapy services should be rendered within the same scientific environment as that of medicine-the community hospital:

A larger experience will bring knowledge that suffering is relieved more quickly and bercer in a hospital than can be done in the patient's home; that by the correction of physical abnormalicies the parienc is able to live a more healthy and happier life; relatives and friends are spared worry and anxiety when the patienc is treated in a hospital. (Dunton, 1922, p. 403)

At the Fifth Annual Meering of NSPOT, Hall urged occupational therapists to rally to obtain positions in hospitals:

I would like ro sugges as the first copic, "The Relationship of the [Occupational Therapy] Aide to the Visiting Doctor, and to the Hospital staff, the Position that the Aide should occupy in Her Relationship with the Other Deparments of the Hospical." We are, as occuparional therapists, a comparatively new type of assistanc. We should not efface ourselves too much and fail to get what belongs to us in the way of opportunity. ("Fifth Annual Meering," 1922, p. 232)

Modern Hospital... is a magazine which is of importance beyond the field of occuparional therapy for you. It covers the hospital field. If you will read from month to month the articles on hospital administration which are included in that magazine-even if you read only the advertisements you will be in closer touch with the hospical system of this country and its requirements. ("Fifth Annual Meering," 1922, p. 226)

Interestingly, Slagle and Upham did not agree that occupational therapy services should be administered only in the hospital setring. Both leaders believed that occupational therapy also belonged in the community (i.e., in home care, the school system, industrial sites) (Collins, 1922; Upham, 1917a, 1917b). Johnson (1919) also cautioned that hospital settings would limit occupational therapy service to isolated physical care without giving consideration to community reintegration. However, these leaders also understood that alignment with medicine was necessary to preserve the perception that occupational therapy was a therapeutic treatment, not a technical vocational training service. During the war, occuparional therapists increasingly provided services only at bedside and within the curative workshops of the hospital setting, within the purview of orthopedists. The vocational shop, headed by vocational trainers, was eventually abandoned by the reconstruction aides (Crane, 1921).

These strategies served to strengthen the affiliation between occupational therapy and medicine in WWI and to disengage occupational therapy from vocational training. The aides were again placed under the charge of the orthopedists who successfully argued that occupational therapy was a medical service, rather than vocational training, and thus required a physician prescrip- tion ("Letter to J. E. Goldrhwait," 1918a). In military literature, orthopedists contended that

\footnotetext{
The use of the curarive work shop is purely physical... and is prescribed as one would prescribe medicine. "Reporr of Orthopedic Surgery l'osition," n.d., p. 6)

The orthopedist uses them [bedside occupations and curative workshop activities] on prescription exactly as he would use drugs. ("Organization of Orthopedic Service," n.d., p. 1)

The primary purpose of the [reconstrucrion] hospital is curative and the vocational education of rhe patient is at all times to be considered as a secondary imporance. (Mumford, 1918, p. 676)
}

An official military circular about the employment of reconstruction aides stated that the work "is regarded as a purely medical function. It is not intended to prepare the man for a vocational choice" (Medical Department, U.S. Army, 1918), and in a letter written to Goldthwait, Brackett asserted that he "has tried to keep [occupational therapy] absolutely removed from any vocational, or even prevocational bearing" ("Letter to J. E. Goldthwait," 1918c).

In civilian life, the occupational therapy leaders promoted professional alignment with medicine through other political and social strategies. Slagle was particularly instrumental in creating a public and professional image of occupational therapy as a medical health profession. In the early 1920s, she organized national American Occupational Therapy Associarion (AOTA) conferences to be held in conjunction with the American Hospital Association (AHA) and the American Medical Association (AMA) ("Fifth Annual Meeting," 1922; "Ninch Annual Meeting," 1925). This strategy afforded occupational therapists an opportunity to educate physicians and hospital administrators about the value of occupational therapy services. It also enabled the early occupational therapy leaders to form necessary social and political connections with hospital administrators to establish internship programs and secure occupational therapy deparments within hospital settings.

Slagle, Kidner, Hall, and Dunton also presented occupational therapy papers at professional conferences, including those of the AHA, AMA, and the National Tuberculosis Associarion ("Fifth Annual Meeting," 1922; Hall, 1917; Slagle, 1938). These occupational therapy leaders enlisted the support of prominent physicians such as Edgar King, Leo Mayer, John Adams, Robert Osgood, Eugene Mumford, and G. Canby Robinson-all occupational therapy proponents - to champion occupational therapy's advancement through conference presentations to their medical colleagues ("Ninth Annual Meeting," 1925; "Reconstruction and Rehabilitation of Disabled Soldiers," 1918; Robinson, 1924). In addition to formal oral presentations, the early occupational therapy leaders and physician allies promoted the profession by publish- 
ing occupational therapy articles in popular medical journals, including Modern Hospital, Mental Hygiene, Journal of the American Medical Association, Trained Nurse and Hospital Review, Boston Medical and Surgical Joumnal, and the American Journal of Orthopedic Surgery (Barton, 1914, 1915; Crane, 1919; Goldthwait, 1917; Hall, 1917; Johnson, 1919; Mayer, 1917; Osgood, 1916).

Because Slagle understood the importance of visibility and professional affiliation, she relocated AOTA's national headquarters to New York City within the same building that housed the National Health Council. She believed that the extra overhead incurred by higher New York Ciry rents was well worth the financial cost to establish a political connection to the leading health organizations in the country ("Ninth Annual Meeting," 1925).

These strategies helped to secure occupational therapy's professional affiliation with medicine and dissolve any public misperception that occupational therapy was nothing more than technical vocational training. To end further persisting public and professional misunderstanding of occupational therapy as a technical trade, Slagle, Hall, and Dunton advocated for occupational therapy education to be carried out within university and college settings (Colman, 1984, 1990; "Ninth Annual Meeting," 1925; Upham, 1917a). Occupational therapists would be required to obtain a university degree-a status that would professionally distinguish occupational therapists from tradesmen schooled only in technical skills.

\section{Summary}

Although the early occupational therapy leaders successfully created a public and professional perception of occupational therapy as a medical health profession, they did so at the expense of the profession's roots in vocational reeducation. Perhaps if events in WWI had not resulted in a schism between occupational therapy and vocational reeducation, occupational therapy today would involve a greater integration of vocational reeducation. The medical reformers of the early 20 th century, who believed that occupational therapy could fill the gap between acute medical care and community reintegration, may have witnessed the germination of their professional ideals and efforts.

Instead, the preindustrial hospital shop envisioned by Kidner never truly materialized, as hospital services increasingly focused on acute care provision. Although medicine supported occupational therapy's physical restoration of joint, muscle, and nerve function, physicians and hospital administrators viewed chronic care practice, community reintegration, and vocational reeducation as alien to the role of the community hospital (Starr, 1982). This situation resulted in the profession's uneasy relationship within a medical model that only supported one half of occupational therapy services - the physical rehabilitation of limbs. Assisting persons with disabilities to perform necessary funcrional activities within their communities (including work) is an aspect of occupational therapy that has been considerably limited by the constraints of practicing primarily within hospital settings.

The decision to deliver services primarily within hospital settings was a choice the early occupational therapy leaders made to enhance the profession's prestige through medical affiliation. However, it was a judgment that compromised the profession's role in vocational reeducation. Ambrosi and Schwartz (1995) argued that when the early occupational therapy leaders decided to dissociate from the vocational aspects of occupational therapy, they missed an opportunity to publicly identify the profession as a service that society values and understands: the restoration of persons to work and community life. In today's present era of health care change, when occupational therapy has been challenged to articulate why its services are socially useful and distinguishable from those of physical therapy, the profession could benefit by more clearly demonstrating that it is the social service that reeducates persons with disabilities to function in their communities as valuable workers and contributors to society.

\section{Acknowledgments}

I thank Rurh L. Schemm, EdD. OTR/L., FAOTA, and Ellen Condliffe Lagemann, PhD, for their cricical review and analysis of this arricle.

\section{References}

Ambrosi, E: \& Schwartz, K. B. (1995). Looking Back-The profession's image, 1917-1925, parc II: Occupacional therapy as represented by the profession. American Joumal of Occupational Therapy, 49, 828-832.

An advisory medical board for the Enmanuel Movement. (1909). Boston Medical and Surgical Journal, 160, 90-91.

Ball, C. B. (1921). The Red Cross school of OT ar Detroit Michigan. Modem Hospital, 16,574.

Barton, G. E. (1914). A view of invalid occupation. Trained Nurse and Hospital Review, 52, 327-330.

Barton, G. E. (1915). Occupational therapy. Trained Nurse and Hospital Review, 54, 138-140.

Barton, G. E. (1920). What occupational therapy may mear to nursing. Nurse and Hospital Review, 64, 304-310.

Chamberlain, W. P. (n.d.). Summary of the Medical Department of the U.S. Army during the war. (Available from the National Archives and Records Administration, 700 Pennsylvania Avenue, NW, Washington, DC 20408-0001, Classification 795131, Record Group 112, 321.6 General, SGO/Orthopedics, 1917-1927, Box 161)

Collins, E. L. (1922). Occupational therapy for the homebound. Archives of Occupational Therapy, 1, 33-40.

Colman, W. (1984). A study of educational policy setting in occupational therapy, 1918-1981. Unpublished docroral dissertation, New York Universiry.

Colman, W. (1990). Looking Back-Recruitment standards and practices in occupational therapy, 1900-1930. American Journal of Occupational Therapy, 44,742-748.

Crane, A. G. (1921). Education for the disabled in war and indus- 
try. New York: Teachers College, Columbia Universiry.

Crane, A. G. (1927). The Medical Department in the World War, wol. XIII: Physical reconstruction and vocational education. Washington, DC: U.S. Government Printing Office.

Crane, B. T. (1919). Occuparional therapy. Boston Medical and Surgical Journal, 181(31), 63-65.

Dunton, W. R., Jr. (1915). Occupational therapy: A manual for nurses. Philadelphia: Saunders.

Dunton, W. R., Jr. (1922). The educational possibilities of occupational therapy in state hospitals. Archives of Occupational Therapy, $I$, 403-409.

Duncon, W. R., Jr. (1928). Prescribing occupational therapy (2nd ed.). Springfield, IL: Charles C Thomas.

Elton, F. G. (1924). Relationship of occupational therapy to rehabilitation. Archives of Occupational Therapy, 3, 101-108.

Federal Board for Vocational Education. (1918). Vocational rehabilitation of disabled soldiers and sailors (Senate Document no. 166). Washington, DC: U.S. Government Printing Office.

Fifth Annual Meeting of the National Sociecy for the Promotion of Occupational Therapy. (1922). Archives of Occupational Therapy, I, 219-240.

Futton, F. W. (1921). The Philadelphia School of Occupational Therapy. Modern Hospital, 16, 572-574.

The function of orthopedic surgery in the war. (1917). Journal of the American Medical Association, 69, 2123.

Goidthwait, J. E. (1917). The orthopedic preparedness of the nation. American Joumal of Orthopedic Surgery, 15, 219-220.

Gorgas chooses Boston. (1918, April). In M. B. Greene scrapbooks. (Available from the Archives of the Boston School of Occupational Therapy, Tufts University, Medford, Massachusetts 021557084)

Greene, M. B., \& Wigglesworth, R. (1921). Boston School of Occupational Therapy, Inc. Modern Hospital, 16, 568-570.

Hall, H. J. (1917). Remunerative occupations for the handicapped. Modern Hospital, 8, 383-386.

Hall, H. J., \& Buck, M. C. (1915). The work of our hands: $A$ study of occupations for invalids. New York: Moffat \& Yard.

Harris, G. (1919). The redemption of the disabled: A study of programs of rehabilitation for the disabled of war and industry. New York: Appleton-Century-Crofts.

Henderson, W. H. (1920). Occupational therapy in Army hospitals. Modern Hospital, 15, 325-327.

Interests of women: New school in Boston. (1918, April). In M. B. Greene scrapbooks. (Available from the Archives of the Boston School of Occuparional Therapy, Tufts University, Medford, Massachuserts 02155-7084)

Johnson, S. C. (1919). Occupational therapy, Modern Hospital, 12, 221-223.

Kidder, I. (1921). St. Louis School of Occupational Therapy. Modern Hospital, 17, 65-66.

Kidner, T. B. (1925). The hospital pre-industrial shop. Occupational Therapy and Rehabilitation, 4, 187-194.

Letter to E. G. Brackett from L. C. Abbott. (1918, January 25). (Available from the National Archives and Records Administration, 700 Pennsylvania Avenue, NW, Washington, DC 20408-0001, Classification 795131, Record Group 112, Entry 29, 211 General, SGO/Orthopedics, 1917-1929, Box 95)

Letter to J. E. Goldrhwait from E. G. Brackett. (1918a, January 23). (Available from the Narional Archives and Records Administration, 700 Pennsylvania Avenue, NW, Washington, DC 204080001 , Classification 795131, Record Group 112, 29 General, SGO/Orthopedics, 1917-1927, Box 431)

Letter to J. E. Goldthwait from E. G. Brackett. (1918b, March
26). (Available from the National Archives and Records Administration, 700 Pennsylvania Avenue, NW, Washingcon, DC 20408 0001 , Classificarion 795131, Record Group 112, 29 General, SGO/Orthopedics, 1917-1927, Box 431)

Letter to J. E. Goldthwait from E. G. Brackett. (1918c, May 21). (Available from the Narional Archives and Records Administration, 700 Pennsylvania Avenue, NW, Washington, DC 20408 0001, Classification 795131, Record Group 112, 29 General, SGO/Orthopedics, 1917-1927, Box 431)

Letter to Sir George Makins from R. Jones. (1918, May). (Available from the National Archives and Records Administration, 700 Pennsylvania Avenue, NW, Washington, DC 20408-0001, Classification 795131, Record Group 112, 29 General, SGO/Orthopedics, 1917-1927, Box 431)

Levine, R. E. (1987). Looking Back--The influence of the artsand-crafts movement on the professional status of occupational therapy. American Joumal of Occupational Therapy, 41, 248-254.

Litterst, T. A. E. (1992). Occupational therapy: The role of ideology in the development of a profession for women. American Joumal of Occupational Therapy, 46, 20-25.

Lynch, C., Weed, F. W., \& McAfee, L. (1923). The Medical Department of the United States Army in the World War, vol. I: Surgeon General's offices. Washington, DC: U.S. Government Printing Office.

Mansfield, H. (1956, March 7). Notes on the formation of war service classes for training reconstruction aides for military hospitals. (Available from the Official Archives of the American Occupational Therapy Association, American Occuparional Therapy Foundation, Wilma L. West Libraty, PO Box 31220, Bethesda, Maryland 208241220, Series 1, Record Group 4, Box 1)

Mayer, L. (1917). The military orthopedic reconstruction hospital. Journal of the American Medical Association, 69, 1522-1524.

Medical Department, U.S. Army. (1918, March 27). Circular of infornation concerning the employment of reconstruction aides. (Available from the Official Archives of the American Occupational Therapy Association, American Occupational Therapy Foundation, Wilma L. West Library, PO Box 31220, Bethesda, Maryland 20824-1220, Series 1, Box 1, Folder 06)

Mumford, E. B. (1918). Application of curative therapy in the workshop. American Joumal of Orthopedic Surgery, 1, 676-681.

Ninth Annual Meeting of the American Occupational Therapy Association. (1925). Occupational Therapy and Rehabilitation, 20, $465-482$.

Occupational therapy at the College of St. Catherine [Bulletin]. (n.d.). (Available from the Official Archives of the American Occupational Therapy Association, American Occuparional Therapy Foundation, Wilma L. West Library, PO Box 31220, Bethesda, Maryland 20824-1220)

Organization of orthopedic service. (n.d.). (Available from the National Archives and Records Administration, 700 Pennsylvania Avenue, NW, Washington, DC 20408-0001, Record Group 112, 321.6 General, SGO/Orthopedics, 1917-1927, Box 159, May-June 1919)

Osgood, R. B. (1916). Orthopedic surgery in war time. Joumal of the American Medical Association, 67, 418-421.

Partridge, C. R. (1921). Milwaukee-Downer College gives OT course. Modern Hospital, 17, 64-65.

Peloquin, S. M. (1989). Looking Back-Moral treatment: Contexts considered. American Joumal of Occupational Therapy, 43, 537-544.

Peloquin, S. M. (1994). Looking Back-Moral treatment: How a caring practice lost its rationale. American Journal of Occupational Therapy, 48, 167-173.

Plan suggested for conducting orthopedic service. (1918, July 2). (Available from the National Archives and Records Administration, 700 Pennsylvania Avenue, NW, Washington, DC 20408-0001, Class- 
ificarion 795131, Record Group 112, 29 General, SGO/Orthopedics, 1917-1927, Box 431)

Quiroga, V. A. M. (1995). Occupational therapy: The first 30 years, 1900 to 1930. Bethesda, MD: American Occupational Therapy Association.

Reconstruction and rehabilitation of disabled soldiers. (1918). Joumal of the American Medical Association, 70, 1924-1931.

Report of orthopedic surgery posirion. (n.d.). (Available from the National Archives and Records Administration, 700 Pennsylvania Avenue, NW, Washington, DC 20408-0001, Classification 795131, Record Group 112,29 General, SGO/Orthopedics, 1917-1927, Box 491)

Robinson, G. C. (1924). The relationship of occupational therapy and medicine. Archives of Occupational Therapy, 4, 1-5.

Schemm, R. L. (1994). Looking Back--Bridging conflicring ideologies: The origins of American and British occupational therapy. American Joumal of Occupational Therapy, 48, 1082-1088.
Schwartz, K. B. (1992). Occupational therapy and education: A shared vision. American Joumal of Occupational Therapy, 46, 12-18.

The scope of a reconstruction hospital. (1917). American Journal of Orthopedic Surgery, 15, 609.

Slagle, E. C. (1938, April). Occuparional therapy. Trained Nurse and Hospital Review, 375-382.

Starr, P. (1982). The social transformation of American medicine. New York: Basic.

Upham, E. G. (1917a). A training course for occupational experrs. Modern Hospital, 9, 458-459.

Upham, E. G. (1917b). Desirability of vocarional educarion and direcrion for disabled soldiers. Extension Division Bulletin of the University of Wisconsin, 1-20.

Vaughn, S. C. (1919). Bedside occupational rherapy. Cary On, $1(6), 13-15$.

Worcester, E., \& McComb, S. (1931). Body, mind, and spirit. Boston: Marshall Jones.

\section{New from AOTA!}

\section{Occupational Therapy Services for}

Children and Youth Under the Individuals With Disabilities Education Act (IDEA)

Essential for all pediatric occupational therapy practitioners and school and early childhood administrators, these guidelines provide a user-friendly approach to understanding and applying IDEA to early intervention and schoolbased practice. These "best practices" guidelines for occupational therapy intervention under IDEA are broken down into five interrelated themes: continuum of care, clients, context, collaboration and partnerships, and outcomes. Case examples and vignettes demonstrate the integration of these themes in actual practice. Also includes:

- A checklist of questions at the end of each section that the occupational therapy practitioner can apply to his or her practice

- Additional resources at the end of each chapter

- Appendix with several pertinent AOTA documents and a list of acronyms of terms common to early intervention and school system settings

240 pages, 1997

Note: These guidelines are based on current law and regulations. IDEA has been reauthorized and was signed into law June 4, 1997 (P.L. 105-17), to go into effect July 1, 1998. The regulations for the implementation of IDEA are currently under development and will be finalized by Spring, 1998. All relevant changes from the 1997 Amendments will be incorporated into this document at that time.

To order,

call 1-800-SAY-AOTA (AOTA members),

301-652-2682 (nonmembers),

or 1-800-377-8555 (TDD users).

shipping and handling additional.

Order \#1177

\$40 AOTA member $\$ 50$ nonmember

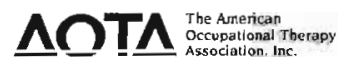

